(C) Yanko N.V.

UDC 616.314.13/.14: 615.24

DOI https://doi.org/10.31718/mep.2020.24.1-2.07

\title{
AGENTS USED FOR ENAMEL REMINERALISATION AND REDUCING DENTIN HYPERSENSITIVITY: A COMPREHENSIVE REVIEW
}

\author{
Yanko N.V.
}

Ukrainian Medical Stomatological Academy

Засоби ремінералізації не тільки посилюють резистентність емалі, але також можуть закупорювати дентинні канальці, знижуючи чутливість зубів. Стаття містить огляд різних доступних агентів, які використовуються для ремінералізації емалі та лікування гіперчутливості дентину. Традиційні фториди, що використовуються у вигляді розчинів, лаків, піни, гелів, зубних паст, продемонстрували низьку ремінералізуючу і десенситизуючу здатність в порівнянні з новими фторумісними продуктами. Глибоке фторування $\epsilon$ ефективним методом зменшення гіперчутливості дентину з тривалим ефектом, його ремінералізуюча здатність використовується для лікування та профілактики початкового карієсу і герметизації фісур. Хоча сполуки фосфату кальцію продемонстрували перевагу перед традиційними фторидами в ремінералізації, їхня десенситизуюча здатність не була підтверджена достатньою кількістю досліджень. Використання біоактивного скла для ремінералізації та зменшення гіперчутливості дентину $\epsilon$ досить перспективним, але щоб довести його ефективність необхідні подальші досліди. «Curodont» і синтетичний наногидроксиапатит із біоміметичних систем показали добрі результати, але для доведення їх клінічної ефективності потрібні додаткові спроби. Немає сумніву, що електрофорез сполук кальцію і фтору залишається найбільш ефективним методом ремінералізуючої терапії, який проводиться на стоматологічному прийомі, проте його потенційний ефект у зниженні гіперчутливості зубів повинен бути краще оцінений. Ефективність різних видів лазерів окремо або в поєднанні з ремінералізуючим агентом була підтверджена в основному дослідженнями in vitro, отже, потрібні клінічні випробування, які доведуть їх переваги. В нещодавних роботах дентинні герметики та десенситайзери, які обтурують дентинні канальці, перевершували традиційні фториди і синтетичні наногидроксиапатити. В той же час дані про ефективність сполук фосфату кальцію та глибокого фторування над дентинними герметиками та інгібіторами нервової чутливості $\epsilon$ суперечливими і вказують на те, що необхідні додаткові досліди для поглиблення наших знань про недостатньо вивчену область зниження чутливості дентину. Незважаючи на нові досягнення, ідеального ремінералізуючого засобу не існує. Останні десятиліття стоматологія зробила значні кроки на шляху до невловимої мети ремінералізації емалі та десенсибілізації дентину, але необхідні довгострокові клінічні контрольовані дослідження для підтвердження та кількісного визначення цих висновків, а також для визначення додаткових факторів, які можуть потенціювати ці процеси.

Ключові слова: ремінералізація, гіперчутливість, десенситизація, емаль, дентин.

Remineralisation agents not only strengthen enamel resistance, but also can occlude dentine tubules, reducing teeth sensitivity. This article provides an overview of various available agents used for enamel remineralisation and dentin hypersensitivity treatment. Conventional fluorides are used in the form of solutions, varnishes, foam, gels, dentifrices, showing low remineralising and desensitising ability as compared to newer fluoride-content products. Deep fluoridation is an effective method for reducing dentin hypersensitivity for a long time; its remineralising potential is used for white spot lesions treatment, caries prevention, and fissure sealing. Most novel fluoride compounds showed higher remineralising and desensitising abilities as compared to conventional fluorides. Deep penetration fluoridation is an effective method for remineralisation and reducing dentin hypersensitivity in long time. Despite of the fact that calcium phosphate systems have demonstrated a benefit over conventional fluorides in remineralisation their desensitising ability was not confirmed by various studies. The use of bioactive glass in remineralisation and desensitisation is quite promising, but further researches need to be undertaken to prove its efficacy. «Curodont» and synthetic nanohydroxyapatite from biomimetic systems showed good results in the above-mentioned treatments, but more researches are required to confirm their clinical efficacy. There is no doubt that iontophoresis with calcium and fluoride substances is still the most effective method in the office remineralisation, however, its potential effect in desensitisation has to be better evaluated. Efficacy of different kinds of lasers alone or in combination with a remineralisation agent has been confirmed mostly in vitro studies, therefore, there is a lack of clinical trials to prove their benefit. In latter studies, dentin sealants and desensitisers occluded dentin tubules were superior to conventional fluorides and synthetic nanohydroxyapatites. Simultaneously, the data about calcium phosphate and deep penetration fluoridation efficacy over such desensitisers as dentin sealants and nerve sensitivity inhibitors are controversial and indicate that additional studies are required to deepen our knowledge of the insufficiently explored area of reducing dentin hypesensitivity. In spite of the new advances, the ideal treatment modality for remineralisation does not exist. Within last decades, dentistry has made significant steps towards the elusive goal of enamel remineralisation and dentin desensitisation, but more long-term clinical controlled studies are needed to confirm and quantify these findings, as well as to identify additional factors that can potentiate these processes.

Key words: remineralisation, hypersensitivity, desensitisation, enamel, dentin.

To cite this English version: Yanko N.V. Agents used for enamel remineralisation and REDUCing dentin hypersensitivity: A Comprehensive review // The Medical and ecological problems. - 2020. - Vol 24, № 1-2. - P. 30-35. 


\section{Introduction}

Dental caries is a result of imbalance between remineralisation and demineralisation. Enamel remineralisation is described as the process of precipitation of calcium and phosphate ions onto the tooth [1]. Fluoride ions are also incorporated into fluor-hydroxyapatite, strengthening the enamel structure, and assist in the enamel remineralisation with phosphate ions dissolved in saliva [2].

Previous reviews have analysed contemporary developments in the remineralisation agents [3-6]. Remineralisation strategies have focused on creating the remineralising scaffolds within the lesions or adding calcium, phosphate, stannous, and arginine to fluoride [5]. Such agents can occlude dentine tubules reducing sensitivity by preventing a dentinal fluid flow. Iontophoresis and lasers potentiate remineralising and desensitising effects of fluoride, calcium and phosphate substances [7, 8]. Unfortunately, there are no studies that review the agents used for enamel remineralisation and dentin hypersensitivity treatment.

The aim of the research was to review the various available agents used for enamel remineralisation and dentin hypersensitivity treatment.

\section{Results and their discussion.}

Fluoride is the most utilized remineralisation agent. In 2010, fluoride was the most common treatment modality and the only treatment for dentin hypersensitivity used frequently by more than 50 percent of American dentists [9]. The distant salts of fluorine used for interventions are: sodium fluoride, sodium monofluorophosphate, stannous fluoride, and acidulated phosphate fluoride.

\section{Conventional fluorides}

Duraphat ${ }^{\circledR} 5000 p p m$ toothpaste (Colgate, USA) with sodium fluoride was effective in caries prevention [10]. Pinto et al. [11] examined the influence of this high fluoride toothpaste and arginine-carbonate toothpaste applications on dentinal tubules exposure followed by an acid challenge. Although no significant differences have been shown between toothpastes, they enhanced resistance of the dentine surface, preventing dentinal tubules exposure after the acid challenge.

The $8 \%$ Arginine-CaCO3 group exhibited statistically significant reduction in the dentin hypersensitivity to day 28 than $1.23 \%$ NaF-gel [12]. Arginine is metabolized by arginolytic bacteria which produce bases increased the $\mathrm{pH}$ in the oral biofilm [13]. However, recent review found insufficient evidence to support a caries-preventive effect for the inclusion of arginine in toothpastes [14].

Systematic review of Marinho et al. [15] revealed that reduction of DMF index in children with fluoride varnish prevention was $43 \%, \mathrm{dmf}-37 \%$, respectively. Unfortunately, fluoride varnishes and gels showed low desensitising ability as compared to other fluoride-content products $[16,17]$.

Silver diamine fluoride (SDF) - Saforide (Neo, Japan) decreased level of hypersensitivity, but it is difficult to compare the obtained results with dates of other studies [18]. Chu et al. [19] found that annual application of SDF was more effective in arresting dentin caries than application of fluoride varnish every 3 months.

\section{Deep-penetration fluoridation}

Deep-penetration fluoridation was invented by $A$. Knappwost, who offered Tiefenfluorid ${ }^{\circledR}$ (Humanchemie, Germany), which consists of two solutions. When applied, the second solution reacts with the first one into the enamel pores or the dentinal tubules occluding them by the crystals of calcium fluoride or magnesium fluoride. A high concentration of fluoride ions provided remineralisation in the combination to calcium, phosphate, fluoride crystals remained into the pores till 2 years [20]. According to Meto et al. [21] $100 \%$ of the second degree dentin hypersensitivity cases were stabilized and successful with Tiefenfluorid $^{\circledR}$ for a long time. Gluftored ${ }^{\circledR}$ (Vladmiva, Russia) and Ftorcalcit ${ }^{\circledR}$ (Lotus, Ukraune) have same content.

Ivanitskiy [16] claimed that after 1 year positive results of desensitising were found in all patients who were treated with oral administration Calcium D3 Nycomed (Takeda AS, Norway) and topical application Gluftored ${ }^{\circledR}$, whereas Desensyl ${ }^{\circledR}$-Vladmiva (Russia), which consist of hydroxyapatite, strontium and potassium chlorides, reduced hypersensitivity in $88,4 \%$ patients, fluoride varnish Belak ${ }^{\circledR-} F$ (Vladmiva, Russia) - in $68,2 \%$, respectively [16]. Yarova et al. [17] used Belagel ${ }^{\circledR} \mathrm{Ca} / \mathrm{P}$ (Vladmiva, Russia) topically for dentin desensitising in the frontal teeth and Ftorcalcit ${ }^{\circledR}$ - in the lateral teeth; intensity of dentin hypersensitivity decreased from 34,7 to $9,67 \%$ at 1 year after the initial treatment. Also deep fluoridation was used for white spot lesions treatment [22], caries prevention [3], and fissure sealing [23].

\section{Calcium phosphate systems}

Presently, the need to enhance the remineralising efficacy of fluoride is largely met by calcium phosphate systems. Desensitisers included calcium phosphate associates with water and occlude the dentinal tubules by the hydroxyapatite crystals. Amorphous calcium phosphate provides a higher degree of this occlusion and facilitates deposition of the hydroxyapatite crystalls on enamel [24]. The research by Guglu et al. [25] is only one of various randomized controlled studies that have demonstrated significantly better remineralising effect of CPP-ACP (Casein Phosphopeptide-Amorphous Calcium Phosphate) paste compared to a fluoride-containing varnish. According to Rosaiah and Aruna [26] CPP-ACP was more effective in reducing dentin hypersensitivity than crystalline calcium phosphate at 6 months after the initial treatment. Peshevar et al. [27] found no significant statistical difference in reduced desensitising in the fluoride varnish and CPP-ACP paste groups at 2 months after the initial treatment. CPP-ACP was significantly better in reducing dentin hypersensitivity compared to propolis and sterile water at 3 weeks after the initial treatment $(P<0.01)$ [28].

Remineralisation effect of CPP-ACP had to be improved in CPP-ACFP (with fluoride). However, Llena et al. [29] did not find significant differences between CPP. ACFP, CPP-ACP and the fluoride varnish in 3-months study. Furthermore, in 3-months research by Madhavan et al. [30] CPP-ACPF was less efficient in comparison to fluoride varnish and propolis. Controversial results of CPP-ACP and CPP-ACFP in dentin hypersensitivity reducing may be explained by the absence of the standard procedure to test desensitisers and the short time of studies.

Freire et al. [31] showed that a 500-ppm low-fluoride dentifrice supplemented with sodium trimetaphosphate (STMP) was significantly superior to a 1100 -ppm fluoride dentifrice in lowering the caries increment of children. Favretto et al. [32] reported that the addition of STMP to fluoride toothpastes produced greater obliteration of the dentinal tubules when compared with 1100-ppm fluoride dentifrice. In vitro Teethmate ${ }^{\circledR}$ desensitizer (Kuraray Noritake Dental, Japan) containing tetra- and dicalcium phosphates applied for 3 times consistently reduced den- 
tin permeability by $50 \%$ after $24 \mathrm{~h}$, whereas fluoride varnish did not achieve such a result [33]. There is a need for additional clinical studies to ascertain whether polyphosphates can influence remineralisation and desensitisation.

\section{Bioactive glass}

Calcium sodium phosphosilicate (CSPS) is a bioactive glass material that initially was incorporated in toothpastes for dentin hypersensitivity. Recent meta-analysis demonstrated that toothpaste containing 5\% CSPS - NovaMin $^{\circledR}$ (GSK, Great Britain) was more effective than the negative control at relieving dentin sensitivity [34]. There are no clinical data from randomised controlled studies to prove its remineralising efficacy, however, in vitro NovaMin $^{\circledR}$ dentifrice appears to have a greater effect on remineralisation of the carious-like lesions when compared to that of the fluoride containing dentifrice in permanent teeth [35].

Fluoride-containing aluminocalciumsilicate nanoparticle glass dispersed aqueous solution - Nanoseal (NAN, Nishin, Japan) is used as a desensitiser. In vitro the tubule occlusion rates of Saforide were significantly lower than those of Nanoseal and Teethmate ${ }^{\circledR}$ desensitiser $(\mathrm{P}<$ 0.05) [36].

\section{Biomimetic systems}

Other promising direction in remineralisation is development of biomimetic systems which help to regenerate hard dental tissues. The first group of them, which does not have commercial products and never has been used in vivo, includes Dentine Phosphoprotein-Derived 8DSS Peptides, amelogenin peptides, Poly (Amido Amine) Dendrimers. These products exhibited a strong tendency to self-assemble into the hierarchical enamel crystal structures [4]. The second group included P11-4 peptides, electrically accelerated and enhanced remineralisation, and nanohydroxyapatite which have used in patients.

P11-4 peptides are represented by self-assembling peptide matrix Curodont Repair ${ }^{\circledR}$ (Curodont, Great Britain) which was rationally designed to promote formation of hydroxyapatite. It has shown promising results as a remineralisation agent in the initial caries regression as compared to fluoride varnish Duraphat ${ }^{\circledR}$ [37]. Schlee et al. [38] showed that desensitiser Curodont D'Senz ${ }^{\circledR}$ gel (Curodont, Great Britain), which was applied within the first week, as compared to $8 \%$ arginine and calcium carbonate toothpaste used throughout the whole 90 day study, resulted in much higher patient satisfaction in the dentin hypersensitivity treatment at day 7 and the higher number of pain-free patients at day 7 and day 90 .

Synthetic nanohydroxyapatite is another bioactive material, whose nano-sized particles can strongly bind to enamel surface and with fragments of plaque and bacteria, acts as a filler to repair small holes and depressions of enamel surface [39]. Nanohydroxyapatite gel had a significant potential for enamel remineralisation around restoration margins [40], but there were no well-designed studies that confirm its high efficacy in comparison to fluoride toothpastes. Synthetic nanohydroxyapatites were effective in the reducing dentin hypersensitivity, but only a few researches dealt with this problem $[41,42]$.

Despite the fact that iontophoresis has been widely used for enamel remineralisation and dentin hypersensitivity treatment in the former Soviet Union countries for 50 years, recently this technique has been introduced as a novel method of tooth remineralisation - electrically accelerated and enhanced remineralisation (EAER) [8]. A lot of studies have confirmed efficacy of iontophoresis with calcium gluconate and sodium fluoride in the prevention and the treatment of caries and non-carious lesions [43]. In the study by Patil et al. [44] iontophoresis with $0.33 \%$ sodium fluoride gel closed $50 \%$ open dentinal tubules. Therefore, more controlled studies with comparable outcomes are still necessary before obtaining a definitive answer to the question may iontophoresis enhance treatment outcomes of dentin hypersensitivity treatment.

\section{Lasers}

Laser irradiation could increase efficacy of desensitising and remineralising agents. Low-energy Er:YAG laser irradiation coupled with fluoride treatment may inhibit enamel demineralization through the photothermal purification of enamel hydroxyapatite, the inhibition of enamel diffusion increased fluoride deposition on the enamel surface, and the formation of fluoridated hydroxyapatite [45]. Moreover, reducing dentin hypersensitivity could be explained by coagulation of proteins of the dentin fluid and discharging of the internal tubular nerve [46].

According to the study by George et al. [47], the diode laser was more efficient in the decrease of teeth hypersensitivity to fluoride toothpaste at day 30 . Umberto et al. [48] demonstrated that the diode laser showed a very high capability to improve immediately the dentin hypersensitivity, both alone and better in combination with $1.25 \% \mathrm{NaF}$ gel. In vitro study by Ahrari et al. [49] found that the application of diode laser through sodium fluoride or CPP-ACPF did not produce any additional effects in enhancing remineralization of white spot lesions, whereas the combined application of diode laser with Remin Pro ${ }^{\circledR}$ (Voco, USA), which is a dentifrice with hydroxyapatite, fluoride and xylitol, was effective.

In vitro study of Asl-Aminabali et al. [50] Nd:YAG laser irradiation with CPP-ACP cream significantly increased mineralisation of artificial white spots for 30 days. In vitro Nd:YAG laser irradiation alone and combined with NovaMin ${ }^{\circledR}$ proved superior to NovaMin ${ }^{\circledR}$ alone on the dentinal tubules occlusion [51].

In vitro studies that support Er:YAG laser superior resistance to demineralisation of dental enamel are controversial $[45,52]$ and can be explained by the absence of standard procedure for evaluation. Yu et al. [53] reported significantly reduced dentin hypersensitivity 4 weeks after the Er:YAG laser desensitization treatment. Further studies are required to evaluate the long-term stability of the obtained positive results and efficacy of this treatment modality.

Efficacy of desensitisers with remineralising effect in comparison to other desensitisers

A lot of researches were dealt with comparison of efficacy of different desensitisers. To enhance the natural repair process by calcium and phosphate from saliva and plaque fluid fluoride is included in desensitisers from other groups. In research by Tumanova et al. [54], the intensity of dentin hypersensitivity at 1 year after the initial treatment was lower with one-time application of dentin sealant Admira ${ }^{\circledR}$ Protect (Voco Gmbh, Germany) in comparison to potassium oxalate based desensitiser Super Seal ${ }^{\circledR}$ (Phoenix dental, USA), and 1-month course of fluoride varnish Bifluorid $12^{\circledR}$ (Voco Gmbh, Germany) or tooth paste with NovaMin Sensodyne ${ }^{\circledR}$ F. Other sealant with fluoride MS Coat F (Sun Medical, Japan) showed higher effect than sealant without fluoride MS Coat One (Sun Medical, Japan) and same effect with dentifrice 
Fluor Jelly (6000 ppF) after acid challenge on extracted teeth [55].

Synthetic hydroxyapatites did not show superiority to desensitisers occluded dentin tubules. Neo Active Apatite powder (Ghimas, Italy) was inferior to desensitiser with glutaraldehyde and potassium fluoride Vivasens ${ }^{\circledR}$ (Ivoclar Vivadent, Liechtenstein) [41]. Unfortunately, this in vitro research did not evaluate resistance of desensitisers to the oral environment. Orsini et al. [42] evaluated three dentifrices: the arginine-based, the strontium acetatebased and the containing zinc-carbonate hydroxyapatite nanocrystals; no significant differences in reducing hypersensitivity were observed in a subset of patients from different groups that were followed up to 2 months.

Mosleh et al. [56] claimed that Curodont D'senz ${ }^{\circledR}$, Propolis extract, and ammonium hexafluorosilicate gel demonstrated effectiveness in alleviating the hypersensitivity symptoms, with propolis extract paste being the most effective within 1 to 2 weeks and sustained up to 3 months.

Acidulated phosphate gel iontophoresis was more effective in reducing dentin hypersensitivity than Adper $^{\circledR}$ Scotchbond $^{\circledR}$ Multi-Purpose Adhesive (3M ESPE, USA) at the end of 2 weeks [57]. According to Konekeri et al. CPP-ACP [58] was significantly more effective than potassium nitrate (nerve sensitivity inhibitor) in reducing cervical dentinal hypersensitivity at 6 weeks' duration. However, Walsh [59] did not find any differences between these agents at such duration and explained these finding by different baseline scores of dentin hypersensitivity.

In vitro study by Yilmaz et al. [60] evaluated the quantitative changes in dentin permeability after desensitiser and following post-treatments. Potassium oxalate desensitiser D/Sense ${ }^{\circledR}$ Crystal (Centrix, USA) was superior to fluoride varnish Bifluorid $12^{\circledR}$ against artificial saliva posttreatment. In this study, authors did not detect a remineralisation effect of the Nupro Sensodyne Prophylaxis Paste with Novamin $^{\circledR}$ following artificial saliva posttreatment for 24 hours. Citric and artificial saliva posttreatments caused some reducing in the efficacy of all studied desensitisers including Gluma ${ }^{\circledR}$ Self Etch bond (Kulzer $\mathrm{GmbH}$, Germany) by partly removing the deposits formed on/within the tubules and caused a reincrease in permeability.

In the research by Budzinsky et al. [61] Gluma ${ }^{\circledR}$ Desensitizer reduced dentin hypersensitivity in almost all patients 12 months after the treatment in comparison to iontophoresis with $2 \%$ sodium fluoride and deep fluoridation. Contrary to the results of this study, Petrushanko et al. [62] claimed that Gluftored ${ }^{\circledR}$ was superior to four HEMA-containing desensitisers: Acua Prep ${ }^{\mathrm{TM}} \mathrm{F}$ (Bisco, USA), Gluma ${ }^{\circledR}$ Detensitizer (Kulzer GmbH, Germany), Seal and Protect ${ }^{\mathrm{TM}}$ (Dentsply, USA), and Butler protect (Butler John O Co), immediately after application; only $10 \%$ patients have dentin hypersensitivity 1 month after Gluftored $^{\circledR}$ using. These results may be explained by different baseline scores of dentin hypersensitivity and a small number of patients.

\section{Conclusions}

Most novel fluoride compounds showed higher remineralising and desensitising abilities as compared to conventional fluorides. Deep penetration fluoridation is an effective method for remineralisation and reducing dentin hypersensitivity in long time. Despite the fact that calcium phosphate systems have demonstrated a benefit over conventional fluorides in remineralisation their desensitising ability was not confirmed by various studies. The use of bioactive glass in remineralisation and desensitisation is quite promising, but further researches need to be undertaken to prove its efficacy. "Curodont» and synthetic nanohydroxyapatite from biomimetic systems showed good results in the above-mentioned treatments, but more researches are required to confirm their clinical efficacy. There is no doubt that iontophoresis with calcium and fluoride substances is still the most effective method in the office remineralisation, however, its potential effect in desensitisation has to be better evaluated.

Efficacy of different kinds of lasers alone or in combination with a remineralisation agent has been confirmed mostly in vitro studies, therefore, there is a lack of clinical trials to prove their benefit.

In latter studies dentin sealants and desensitisers occluded dentin tubules were superior to conventional fluorides and synthetic nanohydroxyapatites. Simultaneously, the data about calcium phosphate and deep penetration fluoridation efficacy over such desensitisers as dentin sealants and nerve sensitivity inhibitors are controversial and indicate that additional studies are required to deepen our knowledge of the insufficiently explored area of reducing dentin hypesensitivity.

In spite of the new advances, the ideal treatment modality for remineralisation does not exist. Within last decades, dentistry has made significant steps towards the elusive goal of enamel remineralisation and dentin desensitisation, but more long-term clinical controlled studies are needed to confirm and quantify these findings, as well as to identify additional factors that can potentiate these processes.

\section{References}

1. Fejerskov O, Kidd EAM. (2008). Dental caries: The disease and its clinical management. Oxford: Blackwell Munksgaard.

2. Cate JMT. In vitro Studies on the Effects of Fluoride on Deand Remineralisation. J Dent Res 1990; 69 (2 suppl): 614619.

3. Chomenko LO, Shapovalova LI. Deep fluoridation method of caries prevention. Part 2. Dentin sealing liquid. Preventive and paediatric dentistry 2013; 1(8): 6-10 [in Ukrainian].

4. Philip N. State of the Art Enamel Remineralisation Systems: The Next Frontier in Caries Management. Caries Res 2018; 53(3): 284-295.

5. González-Cabezas C, Fernández CE. Recent Advances in Remineralisation Therapies for Caries Lesions. Adv Dent Res 2018; 29(1): 55-59.

6. Zero DT. Dentifrices, mouthwashes, and remineralization/caries arrestment strategies. BMC Oral Health 2006; 6 Suppl 1(Suppl 1): S9.

7. Pitts NB, Wright JP. Reminova and EAER: keeping enamel whole through caries remineralisation. Adv Dent Res 2018; 29: 48-54.

8. Liu Y, Hsu CY, Teo CM, Teoh SH. Potential mechanism for the laser-fluoride effect on enamel demineralization. J Dent Res 2013; 92(1):71-75.

9. Cunha-Cruz J, Wataha JC, Zhou L, et al. Treating dentin hypersensitivity: therapeutic choices made by dentists of the northwest PRECEDENT network. J Am Dent Assoc 2010;141(9):1097-1105.

10. Derks A, Katsaros C, Frencken JE, et al. Caries-inhibiting effect of preventive measures during orthodontic treatment with fixed appliances. A systematic review. Caries Res 2004; 38: 413-420.

11. Pinto SC, Bandéca MC, Pinheiro MC, et al. Preventive effect of a high fluoride toothpaste and arginine-carbonate toothpaste on dentinal tubules exposure followed by acid 
challenge: a dentine permeability evaluation. BMC Res Notes 2014; 7 : 385.

12. Uraz A, Erol-Şiimşek Ö, Pehliivan S,et al.The efficacy of $8 \%$ Arginine-CaCO3 applications on dentine hypersensitivity following periodontal therapy: A clinical and scanning electron microscopic study. Med Oral Patol Oral Cir Bucal 2013; 18(2): e298-e305.

13. Huang $X$, Exterkate RAM, ten Cate JM. Factors associated with alkali production from arginine in dental biofilms. J Dent Res 2012; 91:1130-1134.

14. Ástvaldsdóttir Á, Naimi-Akbar A, Davidson T, et al. Arginine and Caries Prevention: A Systematic Review. Caries Res 2016; 50:383-393.

15. Marinho VCC, Worthington HV, Walsh T, Clarkson JE. Fluoride varnishes for preventing dental caries in children and adolescents. Cochrane Database of Systematic Reviews 2013; 7: Art. No.: CD002279.

16. Іваницький І. О. Порівняльна характеристика ефективності лікування гіперчутливості зубів із використанням сучасних препаратів: автореф. дис. на здобуття наук. ступеня канд. мед. наук: 14.01.22 спец. «Стоматологія» / І. О. Іваницький. - Полтава, 2010. - 18 c. [Ivanitskiy IO. Comparative characteristic of the efficacy of teeth hypersensitivity treatment with the using of modern medicines: thesis submitted in fulfilment of the requirement regulations for the degree of doctor of philosophy: 14.01.22 speciality "Stomatology» / IO Ivanitskiy. - Poltava, 2010. 18p].

17. Ярова С.П., Гензицька О.С., Заболотна І.І. Особливості лікування гіперестезії дентину при захворюваннях тканин пародонта. Медицина сьогодні і завтра. - 2011. №3. - C. 143-146. [Yarova C.P., Genzitska O.S., Zabolotna I.I.. Features of the treatment of dentin hyperesthesia at diseases of periodontal tissues. Medicine today and tomorrow 2011; 3: 143-146].

18. Castillo JL, Rivera S, Aparicio, T, et al. The Short-term Effects of Diamine Silver Fluoride on Tooth Sensitivity: a Randomized Controlled Trial. J Dent Res 2011: 90(2):203208.

19. Chu $\mathrm{CH}$, Lo EC, Lin HC. Effectiveness of silver diamine fluoride and sodium fluoride varnish in arresting dentin caries in Chinese pre-school children. J Dent Res 2002; 81: 767-770.

20. Knappwost A. Tiefenfluoridie rungdurch mineralische Schmelzversiegelung. LZAKB 1993; 21:232.

21. 21. Meto A, Meto A, Tragaj E, et al. The Use of Tiefenfluorid for Desensitization of Dentinal Hyperesthesia. Balkan Journal of Dental Medicine 2014;18(2): 85-88.

22. Каськова Л.Ф., Бережна О.Е., Солошенко Ю.І. та ін. Використання препарату Глуфторед у практиці дитячої стоматології // Профілактична та дитяча стоматологія. 2011. - №1(6). - P. 36-37 [Kas'kova LF, Berezhna OE, Soloshenko Yul, et al. Use of medicine "Gluftored" in the practice of paediatric dentistry. Preventive and paediatric dentistry 2011; 1 (6): 36-37].

23. Gans C, Klimek J, Gleim A. Qualität von Fissurenversiegelung mit zwei Fluorid freisetzenden. Versieglermaterialien. Dtsch Zahnärztl Z 1999; 54: 108-111.

24. lafisco M, Esposti DL, Ramírez-Rodríguez GB, et al. Fluoride-doped amorphous calcium phosphate nanoparticles as a promising biomimetic material for dental remineralisation. Scientific Reports 2018; 8(1): [17016].

25. Guclu ZA, Alacam A, Coleman NJ: A 12-week assessment of the treatment of white spot lesions with CPP-ACP paste and/or fluoride varnish. Biomed Res Int 2016; 2016: 8357621.

26. Rosaiah K, ArunaK. Clinical efficacy of amorphous calcium phosphate, G.C. Tooth Mousse and Gluma desensitizer in treating dentin hypersensitivity. Int J Dent Clin 2011; 3 (1):1-4.

27. Pishevar L, Farhad SZ, Mirzakhani M, et al. Comparison the effect of casein phosphopeptide amorphous calcium phosphate and fluoride varnish on dentin hypersensitivity reduction. Caspian J Dent Res 2015; 4(2): 20-26.

28. Torwane NA, Hongal S, Goel P, et al. A clinical efficacy of $30 \%$ ethenolic extract of Indian propolis and Recaldent ${ }^{\mathrm{TM}}$ in management of dentinal hypersensitivity. A comparative randomized clinical trial. Eur J Dent 2013; 7(4): 461-468.
29. Llena C, Leyda AM, Forner L. CPP-ACP and CPP-ACFP versus fluoride varnish in remineralisation of early caries lesions. A prospective study. Eur J Paediatr Dent 2015; 16(3): 181-186.

30. Madhavan S, Nayak M, Shenoy A, et al. Dentinal hypersensitivity: A comparative clinical evaluation of CPP-ACP F, sodium fluoride, propolis, and placebo. J Conserv Dent 2012;15(4):315-318.

31. Freire IR, Pessan JP, Amaral JG, et al. Anticaries effect of low-fluoride dentifrices with phosphates in children: a randomized controlled trial. J Dent 2016; 50: 37-42.

32. Favretto CO, Delbem ACB, Moraes JCS, et al. Dentinal tubule obliteration using toothpastes containing sodium trimetaphosphate microparticles or nanoparticles. Clin Oral Invest 2018; 22: 3021-3029.

33. Zhou J, Chiba A, Scheffel DLS, et al. Effects of a Dicalcium and Tetracalcium Phosphate-Based desensitizer on in vitro dentin permeability. PLoS One 2016; 11(6): e0158400.

34. Zhu M, Li J, Chen B, et al. The Effect of Calcium Sodium Phosphosilicate on Dentin Hypersensitivity: A Systematic Review and Meta-Analysis. PLoS One 2015; 10(11): e0140176.

35. Golpayegani VM, Sohrabi A, Biria M, et al. Reminelization Effect of Topical NovaMin Versus Sodium Fluoride (1.1\%) on Caries-Like Lesions in Permanent Teeth. J Dent (Tehran) 2012; 9(1): 68-75.

36. Han L, Okiji T. Dentin tubule occluding ability of dentin desensitizers. Am J Dent 2015; 28(2): 90-94.

37. Alkilzy M, Santamaria RM, Schmoeckel J, Splieth $\mathrm{CH}$ : Treatment of carious lesions using self-assembling peptides. Adv Dent Res 2018; 29: 42-47.

38. Schlee M, Rathe F, Bommer C, et al. Self-assembling peptide matrix for treatment of dentin hypersensitivity: A randomized controlled clinical trial. J periodont 2018; 89 (6): 653-660.

39. Pepla E, Besharat LK, Palaia G, et al. Nano-hydroxyapatite and its applications in preventive, restorative and regenerative dentistry: a review of literature. Ann Stomatol (Roma) 2014; 5: 108; 5:

40. Juntavee $N$, Juntavee $A$, Plongniras $P$. Remineralisation potential of nano-hydroxyapatite on enamel and cementum surrounding margin of computer-aided design and computer-aided manufacturing ceramic restoration. Int $\mathrm{J}$ Nanomed 2018; 13: 275513: 27.

41. Pathan AB, Bolla N, Kavuri SR, et al. Ability of three desensitizing agents in dentinal tubule obliteration and durability: An in vitro study. J Conserv Dent. 2016;19(1): 31-36.

42. Orsini G, Procaccini M, Manzoli L, et al. A 3-day randomized clinical trial to investigate the desensitizing properties of three dentifricies. J Periodontal 2013; 84(11): e65-73.

43. Профрілактика стоматологічних захворювань: підручник для студентів стоматологічних фракультетів закладів вищої медичної освіти / [Л.Ф. Каськова, Л.І.Амосова, О.О. Кулай та ін.]; за ред. проф. Л.Ф.Каськової; УМСА. 2-ге вид., перероб., доповн. - Полтава: ТОВ «АCMI», 2018. - 403 c. [Prevention of stomatological diseases: textbook for students of stomatological departments of institutions of higher medical education] [LF Kas`kova, LI Amosova, OO Kulaj, et al.]; LF Kaskova, editor; UMSA, 2d edition. - Poltava: ASMI, 2018. - 403p.].

44. Patil AR, Varma S, Suragimath $G$, et al. Comparative evaluation of efficacy of iontophoresis with $0.33 \%$ sodium fluoride gel and diode laser alone on occlusion of dentinal tubules. J Clin Diagn Res 2017; 11: ZC123-ZC126.

45. Nelson DGA, Wefel JS, Jongebloed WL, Featherstone JD. Morphology, histology and crystallography of human dental enamel treated with pulsed low-energy infrared laser radiation. Caries Res 1987;21(5):411-426.

46. Sgolastra F, Petrucci A, Gatto R, Monaco A. Effectiveness of laser in dentinal hypersensitivity treatment: a systematic review. J Endod 2011; 37:297-303.

47. George VT, Mathew TA, George N, et al. Efficacy of diode laser in the management of dentin hypersensitivity following periodontal surgery. J Int Oral Health 2016; 8(1):103-108.

48. Umberto R, Claudia R, Gaspare P, et al. Treatment of dentine hypersensitivity by diode laser: a clinical study. Int $\mathrm{J}$ Dent 2012:858950. 
49. Ahrari F, Mohammadipour HS, Hajimomenian L, FallahRastegar A. The effect of diode laser irradiation associated with photoabsorbing agents containing remineralizing materials on microhardness, morphology and chemical structure of early enamel caries. J Clin Exp Dent 2018;10(10): e955e962.

50. Asl-Aminabadi N, Najafpour E, Samiei M, et al. LaserCasein phosphopeptide effect on remineralisation of early enamel lesions in primary teeth. J Clin Exp Dent 2015; 7(2): e261-e267.

51. Farmakis ET, Eleftherios-Terry R, et al. In Vitro Evaluation of Dentin Tubule Occlusion by Denshield and Neodymiumdoped Yttrium-Aluminum-Garnet Laser Irradiation. J Endodont 2012; 38(5): 662 - 666.

52. Ceballos-Jiménez AY, Rodríguez-Vilchis LE, ContrerasBulnesR, et al. Acid resistance of dental enamel treated with remineralising agents, Er:YAG laser and combined treatments. Dent Med Probl 2018; 55(3): 255-259.

53. Yu C-H, Chang $\mathrm{Y}-\mathrm{H}$, Clinical efficacy of the Er:YAG laser treatment on hypersensitive dentin. J Formos Med Assoc 2014; 113 (6): 388-391.

54. Туманова С.А., Рубежова Н.В. Клиническая эффективность некоторых средств, применяемых для лечения и профилактики гиперестезии зубов // Институт Стоматологии. - 2009. - №4(45). - C. 66-67 [Tumanova SA, Rubezhova NV. Clinical efficacy of some medicines used for treatment and prevention of dental hyperesthesia Institute of stomatology 2009; 4(45): 66-67].

55. Kawamura K, Kunimatsu Y, Takafumi Nakano T, et al. Antidemineralisation effect of desensitizer containing copolymer and sodium fluoride on root dentin - a transverse microradiographic study. Acta Biomater Odontol Scand 2019: 5(1): 38-43.

56. Mosleh A, Niazy M, El-yassaky M. Clinical and Laboratory Evaluation of the Efficacy of Three Different Treatment Mo- dalities in Management of Dentin Hypersensitivity. Al-Azhar Dent J 2018; 5(2): 129-134.

57. Aparna S, Setty S, Thakur S. Comparative efficacy of two treatment modalities for dentinal hypersensitivity: A clinical trial. Indian J Dent Res 2010; 21, 544-548.

58. Konekeri V, Bennadi D, Manjunath M, et al. A Clinical Study to assess the Effectiveness of CPPACP (Casein Phosphopeptide-Amorphous calcium phosphate) versus Potassium-nitrate (KNO3) on cervical dentine hypersensitivity. J Young Pharm 2015; 7(3): 217-224.

59. Walsh LJ. The effects of GC Tooth Mousse on cervical dentinal sensitivity: A controlled clinical trial. Int Dent SA 2010; 12(1): 4-12.

60. Yilmaz NA, Ertas E, Orucoğl H. Evaluation of Five Different Desensitizers: A comparative dentin permeability and SEM investigation in vitro. Open Dent J 2017; 11: 15-33.

61. Будзинский Н.Э., Сирак А.Г., Арютюнов А.В. Сравнительный анализ эффективности лечения гиперестезии твердых тканей зубов с использованием препаратов на основе соединений фтора и глутаральдегида // Современные проблемы науки и образования. - 2014. №1. - C. 1-7 [Budzinskiy NE, Sirak AG, Arutyunov AV. Comparative analysis of the effectiveness of the dental hyperesthesia treatment using medicines based on fluorine and glutaraldehyde compounds. Contemporary problems of science and education 2014; $1: 1-7]$

62. Петрушанко В.М., Павленкова О.В., Павленко С.А. та ін. Аналіз та застосування різних груп десенситайзерів для лікування гіперестезії // Вісник проблем біології i медицини. - 2017. - №2(138). - C.208-210 [Petrushanko V.M., Pavlenkova O.V., Pavlenko S.A., et al. Analysis and application of different groups of desensitisers for treatment of hyperesthesia. Bulletin of problems in biology and medicine 2017; 2 (138): 208-210].

Матеріал надійшов до редакції 20.12.2019. 